\title{
Reform of Library Management and Service under the New Situation
}

\author{
Qiang Zhao ${ }^{1}$ \\ ${ }^{1}$ Xi'an Iternational University, Xi'an, Shaanxi, 710105 \\ 54892713@163.com
}

Keywords: The New Situation; Library; Management and Services; Reforms

\begin{abstract}
Under the new circumstances of the information age, the reform of the management system and library services, the library has become the way to get rid of the inevitable requirement of the current issues, it is a necessary requirement to adapt the library's future development. University Library managers should be based on library management and service internal and external environment changes, in terms of reform and innovation management system, enrich and improve services, service mode and other aspects, the establishment of library management services in a manner consistent with the new situation, to promote books Museum healthy development, give full play to the role of the library.
\end{abstract}

\section{Introduction}

In the wave of digitization and information technology, people's life philosophy, way of life has changed dramatically, the traditional library management and service concepts exposed many problems, one way or the face of management services has been unable to meet the requirements of the new situation, the traditional library management and service mode can not adapt to the social development needs. Therefore, the library needs to be based on traditional management services, according to the times demand innovation and improvement of library management and services to enable the library to keep up with the pace of development.

\section{Library Services Reform Measures}

Reform moves thrust library endogenous development, but also focus on the performance of the future development of the library. In the network environment, library services reform is an important way for future library development. Library services in the reform, the need to uphold the concept of service, service content, service Reform, to provide readers with personalized service, and fully meet the needs of readers.

Reform Service Concept. The reform of the service concept, change the service concept is carried out services, based on the concept of service content service reform and change may push service mode services reform and achieve sustainable development library. Thus, librarians should focus on innovation and reform service philosophy of "seeking development, seeking coexistence," the guiding ideology, the correct implementation of the service behavior. Service concept should permeate "the people" thought, the people thought to implement in each of the service work, removing barriers between libraries and readers, forming a harmonious relationship and enhance the reader and library, the feelings between reading.

Innovative Services to Manage Content. Current service library services over a single, unable to adapt to environmental requirements pluralistic society. Thus library services need to continue to deepen and expand the scope of services, services tend to focus on professional services and vertical adaptation readers library service requirements. Due to the specialized vertical services for managers also put forward higher requirements, librarians need to be higher professionalism, ahead of consciousness provide specialized vertical services, to carry out targeted services according to the needs of readers work [1]. In addition, managers also need to establish a good understanding of the job, the personal value and position value combined with a positive attitude in order to do service work, practice the "people" of specialized vertical services. 
Change Service Mode. Currently widely used library automation integrated service management systems, to provide readers with an automated retrieval tool, readers can quickly find information and periodicals library holdings information. Readers can also direct the development of books retrieved via a retrieval system, and the development of direct appointment and advances of registered holdings. In traditional lending, while the integrated automation system via the library website directory inquiry system, loan system, library home page is connected, the reader can use any computer terminal query, browse library books and catalogs, to achieve pinpoint, reduce blindness, both to improve libraries utilization, but also save the reader's time.

Libraries also need to strengthen reader education and training, improve the quality of library services. Such as the development library guide, so that readers are familiar with and master the use of library tools methods in a short time, or the use of video presentation to explain the knowledge retrieval and search tools, allowing readers to use the search tools are more intuitive understanding, the reader quickly grasp open the key of knowledge [2]. The last train independent readers acquisition, evaluation methods and the use of literature, so grasp the museum existing resources on the basis of students, using a network of independent retrieval tool knowledge, improve readers use the Internet, the ability to retrieve the tool.

Carry Out Personalized Service. Books pipe service objects for the reader, and the reader's needs vary, so earnestly Library Service Intelligence is the key to the development of personality management services, to provide readers with specific guidance services to meet the individual needs of readers. Moreover, personalized service is an initiative of the service, Library Service from passive to active, to really let the "library into the reader" effect. Personalized service is also reflected in the widening service areas, enhancing the quality of service. Conduct personalized services face different needs of different audiences, demand a broader range of readers involved. Thus personalized service can not be limited to a certain area, and should continue to broaden the scope of services, promote deepening reform service model, libraries can better adapt to the development of a pluralistic society, and in accordance with the changing needs of society and continue to make adjustments [3].

\section{Library Management Reform Measures}

Library management system is the basis of quality of service and assurance, library services at the same time in the reform, more attention should be paid library management reform, to improve library services to provide institutional guarantees.

Strengthen the Management Team Building. High quality library services that depend on high-quality management team, under the new situation librarian needs based on the content of the current service, service mode requirements, change management awareness, establish new service concept, improve service quality and business level, the establishment of a systemically expertise, skilled intelligence service to collect and research, librarians personnel Document Retrieval Course. Especially in the network environment, the ability to work librarian readers have higher requirements, librarians not only need to have computer skills, knowledge of Library and Information Science, literature searching skills, but also need to have some language skills. Therefore, the library must recommend a high level according to the requirements of the new situation and diversified administrator team.

Based on this, libraries need to create conditions and actively introduce with computer knowledge, knowledge of library management personnel, the status quo to change a single personnel structure. Strengthen existing personnel training to encourage staff to participate in in-service management training in professional competence, such as providing job opportunities for graduate students and the like. Libraries need also need to increase investment, provide opportunities and assistance to service managers to receive training, and continuously improve business suiping management personnel, providing efficiency. Management personnel receive education and training but also a good learning atmosphere, have a positive impact on the audience [4]. 
Strengthen Professional Ethics. As libraries serve a single, heavy workload, lack of professionals and the lack of systematic training, active service managers consciousness. The Reform library service requirements librarian must have service awareness, actively providing readers with library services, especially after the Library of personalized service, librarians should have more active service awareness, establish warm and thoughtful, highly responsibility service concept, downtown resistant form of hardship, Gan human ladder spirit. Awareness librarian, philosophy and spirit relies on good professional ethics, and thus the need to strengthen ideological and political work in the library manager, establish advanced models of ethical fashion, forming a good moral atmosphere and environment in which the librarian form compliance concept of ethics guidelines. In addition, books tube further work needs to establish a sound service system, standardize the behavior of librarians, librarian conscientiously fulfill their urge ethics.

Library Management System Reform and Innovation. Management innovation is the re-integration of resources, coordination of management activities, improves resource utilization and management efficiency. Libraries can learn modern enterprise management system and operation mode, the library as a "corporate" business, with market mechanisms and market-based instruments management library. Through external expansion market, within the grasp management, to establish an effective restraint mechanism to stimulate the enthusiasm of librarians, to ensure the realization of social benefits on the basis of certain economic benefits libraries, to provide funding for the development of libraries, library difficult to change the status quo, libraries realize sustainable development.

Under information environment, libraries need innovative management tools to improve the technological content of library management tools to improve the efficiency of library management. Information age, libraries facing internal and external double impact, the impact of information technology in the amount, the library as a social and cultural undertaking, "gas station", the degree of social development also reflects the technological level of the library [5]. Thus libraries need to follow the technology trend of social development, seize the convenience brought about by technological development, and actively respond to the impact of information technology. Specifically, the library needs to be updated library information inquiry, retrieval, and improve information retrieval systems and resources, to provide readers with a better service, the library can better play the role of heritage of civilization. In addition, with the increasing demand of readers, the library can not fully meet the needs of readers, and resource sharing between libraries, interlibrary loan system can be extended library of resources to meet the "tricky" requirements. Therefore should establish an information sharing system between libraries, readers can get the content of other libraries through a library.

Libraries need to reform the personnel system, the market competition mechanism into the personnel system reform, the establishment of a fair, just and open job recruitment, appraisal system and create a fair competition environment for personnel, increase the sense of crisis and librarians sense of competition, to promote library management members active learning and improve individual levels, establish a modern service concept and awareness, improve library service quality. Introduction of competition in line with the future development needs of all libraries, the core of future competition between libraries is the quality of service competition, competition in the fundamental quality of service lies in the level of competition of Human Resources, Human Resources level and innovation are the Library the internal motivation to achieve sustainable development. Librarian can "in its place, being to seek" earnestly fulfill their duties and obligations, management and quality of library services will change fundamentally.

The purpose of reform is to liberate the library resources to maximize the role of resources. Management have a fundamental impact on the management efficiency, the library needs according to the requirements of social development, the reader needs to constantly innovate to improve management, improve management efficiency. Although the library has a public property, but the Reform of Library Management market reforms need to learn ways to the needs of readers of this "market" oriented, with modern high-tech achievements, the reform of the traditional library service model, to make the library collection Document collection, education, information transfer 
functions, the development of literature resources in one, breaking the traditional management model, the creation of new models, improve market information, education and knowledge of the market share. Based on this, the library should focus on doing the personnel system, distribution system and management reforms, such as improving personnel employment system, the implementation of the distribution system have incentive effects, the establishment of project topics mechanisms, symptoms implement library to the "market" reforms.

\section{Conclusion}

Under the new situation, the library needs to actively respond to the challenges brought about by the high-tech, library management and services also have the new changes, the traditional one and full-filled passive service model has been unable to adapt to the information age requirements. Libraries should follow the development trend of the times, based on library problems and development needs, the use of high-tech benefits, reform of library management and service concept, content and mode, to establish a "market-oriented" management model and active service model to enhance the library management and service quality, and promote the development of library construction, library services play better social, cultural and civilization heritage features.

\section{References}

[1] Shi Yuzhen. Development and Strategy Research Library Information Service Under The New Situation .Enterprise Reform And Management, 2015,14: 195 + 214.

[2] Wang Lei. Reform Discussion on New Situation of Library Management and Service . Intellect, 2015,29: 332.

[3] Wu Min. New Thoughts Library Management Services Under The New Situation.. Heihe Science Journal, 2013,12: 170-171.

[4] Wang Xiaojun. University Library Under The New Situation Management Service Platform. Heilongjiang College Of Education, 2009,03: 103-104.

[5] Zhuang Shuqiu. New Situation, How Do The University Library Management And Services. Chinese Securities And Futures, 2011,02: 69-70. 